\title{
カドミウム腎症のスクリーニング検査としての 尿タンパク，尿糖定性・定量試験の検討
}

\author{
青 島 恵子, 加 藤 輝 隆, 寺 西 秀 豊, 加 須 屋 実
}

富山医科薬科大学医学部公衆衛生学教室

\author{
Evaluation of Qualitative and Quantitative Tests for Proteinuria and \\ Glucosuria as Screening Tests for Cadmium-induced Renal Tubular Dysfunction \\ Keiko Aoshima, Terutaka Katoh, Hidetoyo Teranishi and Minoru Kasuya \\ Toyama Medical and Pharmaceutical University, Faculty of Medicine, \\ Department of Public Health, Toyama
}

To evaluate the screening tests for cadmium-induced renal tubular dysfunction, qualitative and quantitative tests for urinary protein and glucose have been done in 146 urine samples obtained from subjects who had lived in the cadmium-polluted Jinzu River basin in Toyama Prefecture, Japan. The subjects consisted of 66 men and 80 women aged 55 to 71 years with $\beta_{2}$-microglobulinuria exceeding 1,000 $\mu \mathrm{g} / \mathrm{g}$ creatinine. The results obtained from this study were as follows;

1) The positive reaction (above $1+$ ) for protein by the dipstick method was seen in $19.7 \%$ of men and $20.0 \%$ of women, and for glucose using Tes-tape in $48.5 \%$ of men and $33.8 \%$ of women.

2) The geometric means of protein and glucose concentrations in urine were $16.4 \mathrm{mg} / \mathrm{d} l$ and $12.7 \mathrm{mg} /$ $\mathrm{d} l$ in men, and $14.2 \mathrm{mg} / \mathrm{d} l$ and $6.8 \mathrm{mg} / \mathrm{d} l$ in women, respectively.

3) The criteria of the primary screening in the health survey system for the residents in cadmiumcontaminated areas conducted by the Japan Environment Agency were a proteinuria level exceeding 10 $\mathrm{mg} / \mathrm{d} l$ and a glucosuria above $( \pm)$ with Tes-tape. Nearly all subjects with urinary $\beta_{2}$-microglobulin exceeding $30 \mathrm{mg} / \mathrm{g}$ creatinine were screened by these criteria in both sexes, whereas only $52.9 \%$ of men and $30.0 \%$ of women who had urinary $\beta_{2}$-microglobulin between 10 to $30 \mathrm{mg} / \mathrm{g}$ creatinine could be screened in this manner. These results indicate that semiquantitative tests are insufficient as initial tests for screening cadmium-induced renal tubular dysfunction.

Key words : Cadmium, Screening, Urinary protein, Urinary glucose, $\beta_{2}$-Microglobulin カドミウム, スクリーニング, 尿タンパク，尿糖， $\beta_{2}$-マイクログロブリン

\section{緒}

\section{言}

全国各地のカドミウム環境污染地域住民を対象にした 健康影響調査が，環境庁により昭和51年から59年度にわ

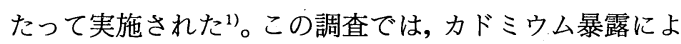
ってもっとも早期に出現する腎臓障害（尿細管障害）の 発見に主眼が置かれた。調査方法は，第 1 次の A と B, 第 2 次，第 3 次の 4 段階に分かれており，第 1 次 $\mathrm{A}$ のス クリーニングの規準は, Kingsbury-Clark $(\mathrm{K}-\mathrm{C})$ 法によ る尿タンパク $10 \mathrm{mg} / \mathrm{d} l$ 以上，かつテス・テープ法による
尿糖（土）以上である ${ }^{1)} 。$

他方著者らは, 富山県神通川流域カドミウム污染地住 民を対象に，尿細管障害の早期指標として尿 $\beta_{2}$-マイク ログロブリンを用いた疫学調查を実施し ${ }^{2)}, 1,000 \mu \mathrm{g} / \mathrm{g}$ クレアチニン以上の高 $\beta_{2}$-マイクログロブリン尿例にお ける，テス・テープ法（士）以上の尿糖陽性率は $36 \%$ に すぎないことを報告しだ)。

本報では，カドミウム腎症のスクリーニング試験とし ての尿タンパク，尿糖の定性・定量試験の再評価を行う 目的で，第 1 に，尿中タンパク定量法として最近広く用 
いられている Coomassie-brilliant-blue G-250 法 (CBB 法)と，従来よりスクリーニングに用いられてきた $\mathrm{K}-\mathrm{C}$ 法との比較検討を行った。第 2 に, 尿 $\beta_{2}$-マイクログロブ

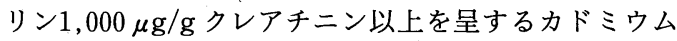
污染地住民の尿タンパク，尿糖定性・定量試験成績と尿 $\beta_{2}$-マイクログロブリン值との関連について検討した。

\section{対象と方法}

1. 尿タンパク定量法のスルホサリチル酸法 ( $\mathrm{K}-\mathrm{C}$ 法) と Coomassie-brilliant-blue G-250 法 (CBB 法) との比 較検討

$\mathrm{K}-\mathrm{C}$ 法と CBB 法を比較するために, 早朝尿 167 検体に ついて両方法で測定した。測定用の尿検体は，3\%酢酸 を加え弱酸性にし, $-20^{\circ} \mathrm{C} て ゙$ 涷結保存した。 $\mathrm{K}-\mathrm{C}$ 法は, 濾 過して完全に透明化した尿 $0.5 \mathrm{~m} l に 3 \mathrm{~g} / \mathrm{d} l$ スルホサリ チル酸一 $7 \% \mathrm{Na}_{2} \mathrm{SO}_{4}$ 溶液 $2.5 \mathrm{~m} l$ を加えて混合し, 室温 に 7 分間放置後ゆるやかに転倒混和し, $620 \mathrm{~nm}$ の吸光度 を測定した4)。CBB 法はトネイン-TP（大塚アッセイ） を用い, 尿50 $\mu l$ に呈色試薬 $3 \mathrm{~m} l$ を加え混和後, $590 \mathrm{~nm}$ の吸光度を測定した。標準液は, 両方法ともトネイン-TP 添付のヒト血清アルブミンを用いた。

2 . 高 $\beta_{2}$-マイクログロブリン尿例の尿タンパク, 尿糖 の定性・定量試験方法

富山県神通川流域カドミウム污染地住民を対象にした

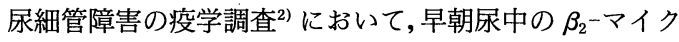
ログロブリンが $1,000 \mu \mathrm{g} / \mathrm{g}$ クレアチニン以上であった 男70人 ( $56 \sim 71$ 歳, 平均 63.2 歳), 女 85 人 (55 71歳, 平 均62.3歳）を対象にした ${ }^{3)}$ 。朝食を攝らない空腹状態で, 午前 8 時から 10 時までの 2 時間尿を採取した。尿 $\mathrm{pH}$ を $\mathrm{pH}$ メーター(東亜電波工業, HM-12A) で測定した。尿 タンパクと糖の定性試験は, 尿検査多項目複合試験紙(ウ ロラブスティックIII，マイルス・三共）を用いた。尿糖 についてはさらに, テス・テープ（塩野義製薬）による 検査を次のように行った。試験紙の端をわずか $(5 \mathrm{~mm})$ に浸し直ちに引き上げ，正確に 1 分後に試験紙内を浸透 し移動した尿先端部と非浸透部の境界部分の呈色を判定 した5)。わずかにでも緑色を呈したときは弱陽性とし，陽 性以上は色調表と比較して判定した。定性試験は判定者 間誤差を防ぐために，同一人が全検体について判定した。

定量試験は, 尿タンパクは CBB 法, 糖は酵素法(Glucose C-Test Wako, 和光純薬工業)， $\beta_{2}$-マイクログロ ブリンは radioimmunoassay 法（ $\beta_{2}$-マイクログロブリ ン“栄研’, 栄研化学), クレアチニンは Folin-Wu 法 (ク レアチニンーテストワコー, 和光純薬工業)によった。な
お，女性の結果のうち尿 $\beta_{2}-$ マイクログロブリンと尿糖 との関連については他の論文でも報告した ${ }^{3)} 。$

$$
\text { 結果 }
$$

1. 尿タンパク定量法の $\mathrm{K}-\mathrm{C}$ 法と $\mathrm{CBB}$ 法の比較

早朝尿 167 検体の $\mathrm{K}-\mathrm{C}$ 法と $\mathrm{CBB}$ 法による尿タンパク 濃度の相関を, Fig. 1 に示した。相関係数 0.818 と有意な $(p<0.001)$ 相関をみたが, 両者の值は一致せず回帰直線 式 $\mathrm{y}=0.50 \mathrm{x}+1.10(\mathrm{x}: \mathrm{CBB}$ 法, $\mathrm{y}: \mathrm{K}-\mathrm{C}$ 法 $)$ と $\mathrm{CBB}$ 法 が平均1.8倍の高值を示した。この回㷌直線式より $\mathrm{K}-\mathrm{C}$ 法による $10 \mathrm{mg} / \mathrm{d} l$ は, $\mathrm{CBB}$ 法では $18.0 \mathrm{mg} / \mathrm{d} l$ に相当し た。

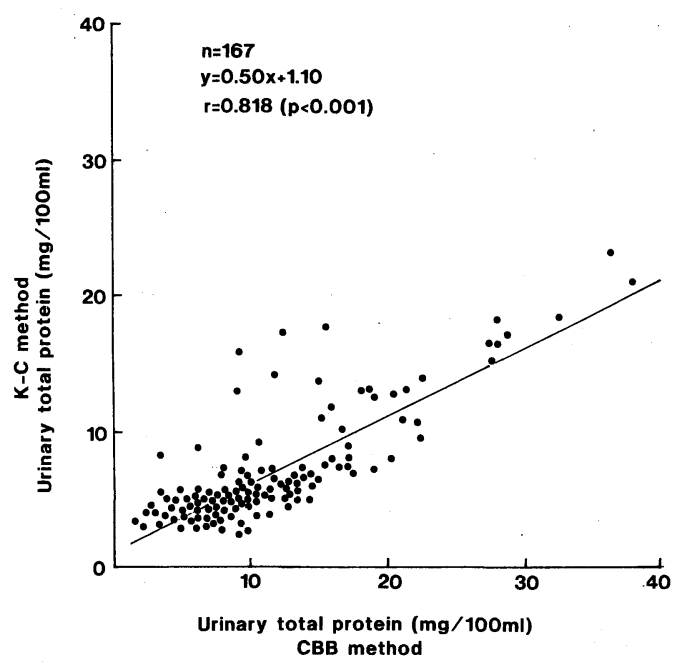

Fig. 1 Comparison between the Coomassie brilliant blue G-250 (CBB) method and the Kingsbury-Clark (K-C) method for measuring urinary total protein.

2. 高 $\beta_{2}$-マイクログロブリン尿例の尿タンパク, 尿糖 の定性・定量試験によるスクリーニングの検討

1 ）尿 $\beta_{2}$-マイクログロブリンの $\mathrm{pH}$ による影響

尿 $\beta_{2}$-マイクログロブリンは, 尿の $\mathrm{pH}$ や温度による 影響を受け易く, pH 5.6〜 5.7以下で急に不安定性を増 し, 変性することが知られている 85 人の尿 $\mathrm{pH}$ と $\beta_{2}$-マイクログロブリン值との関連を示 した。pH 5.8末満の尿は, 男女各 3 例にみられたが, Fig. 2 にみるように, これら 6 例においてとくに著しい $\beta_{2}-$ マ イクログロブリン值の低下はみられなかった。本報にお ける尿検体は 2 時間尿であり, 膀胱における貯留時間が 短いことから, $\mathrm{pH}$ による $\beta_{2}$-マイクログロブリンへの影 


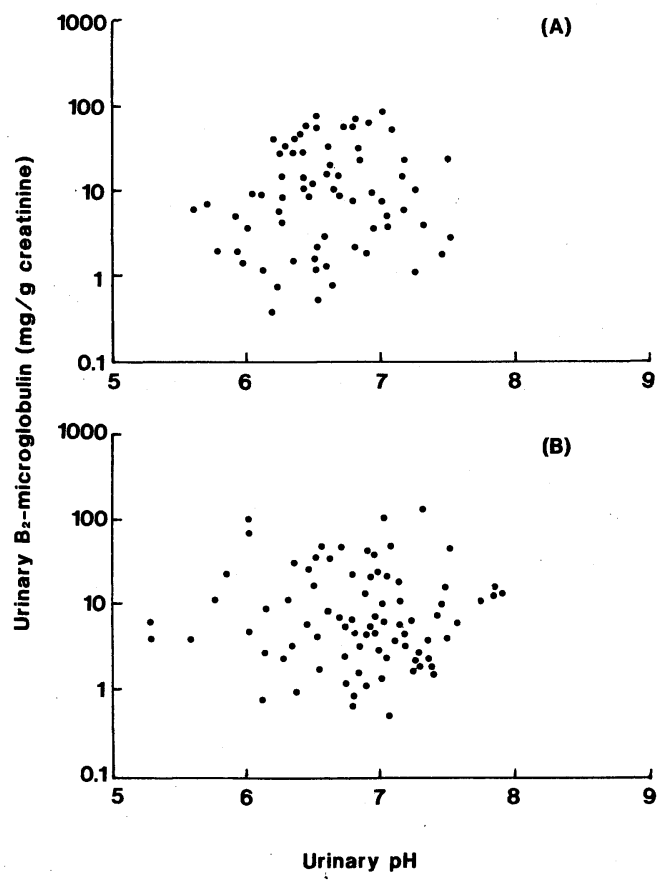

Fig. 2 Relationship between $\mathrm{pH}$ and the concentration of $\beta_{2}$-microglobulin in urine from 70 men (A) and 85 women (B).
響は小さいと考え, pH 5.8未満の尿 6 検体も含めて解析 した。

2 時間尿の $\beta_{2}$-マイクログロブリンの幾何平均值（範

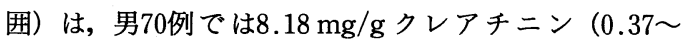
$84.53 \mathrm{mg} / \mathrm{g}$ クレアチニン), 女85例では $7.09 \mathrm{mg} / \mathrm{g}$ クレ アチニン $(0.50 〜 137.76 \mathrm{mg} / \mathrm{g}$ クレアチニン) であった (Fig. 2)。今回の対象は, 早朝尿中の $\beta_{2}$-マイクログロブ

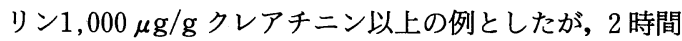
尿の $\beta_{2}$-マイクログロブリン值は男 4 例, 女 5 例が 1,000 $\mu \mathrm{g} / \mathrm{g}$ クレアチニン未満であった。そこで, 高 $\beta_{2}$-マイク ログロブリン尿例における尿タンパク, 糖の定性・定量 試験成績の解析には， 2 時間尿の $\beta_{2}$-マイクログロブリ ン值 $1,000 \mu \mathrm{g} / \mathrm{g}$ クレアチニン以上の男66例, 女80例を対 象とした。

2 ）尿 $\beta_{2}$-マイクログロブリン值別尿定性試験成績

Table 1 に, 対象男 66 人, 女 80 人を尿 $\beta_{2}$-マイクログロ ブリン值別に 4 群に分け, 尿タンパクと尿糖（テス・テ 一プ)の試験紙法による成績をまとめた。尿タンパク（十） 以上の陽性率は男 $19.7 \%$ (13人)，女 $20.0 \%$ (16人) であ った。尿 $\beta_{2}$-マイクログロブリン值別の陽性率は, 尿 $\beta_{2}$ マイクログロブリン值が高くなるにしたがい増加したが, $30 \mathrm{mg} / \mathrm{g}$ クレアチニン以上でも陽性率は40〜 50\%であ つた。試験紙法の感度を知るために, 判定規準別に尿夕 ンパク濃度分布を検討した。その結果, (一)の最高濃度

Table 1 Results of screening tests for proteinuria and glucosuria with a dipstick in 146 individuals with $\beta_{2}$-microglobulinuria living in the cadmium-polluted Jinzu River basin.

\begin{tabular}{|c|c|c|c|c|c|c|}
\hline \multirow[b]{3}{*}{$\begin{array}{l}\text { Number of } \\
\text { subjects }\end{array}$} & \multicolumn{5}{|c|}{$\beta_{2}$-microglobulin (mg/g creatinine) } & \multirow[b]{2}{*}{ Total } \\
\hline & & $1-3$ & $3-10$ & $10-30$ & $30<$ & \\
\hline & $\begin{array}{l}\text { Men } \\
\text { Women }\end{array}$ & $\begin{array}{l}15 \\
18\end{array}$ & $\begin{array}{l}20 \\
29\end{array}$ & $\begin{array}{l}17 \\
20\end{array}$ & $\begin{array}{l}14 \\
13\end{array}$ & $\begin{array}{l}66 \\
80\end{array}$ \\
\hline \multicolumn{7}{|l|}{ Proteinuria } \\
\hline Negative & $(-)$ & $\begin{aligned} 7 & (46.7 \%) \\
11 & (61.1 \%)\end{aligned}$ & $\begin{aligned} 9 & (45.0 \%) \\
18 & (62.1 \%)\end{aligned}$ & $\begin{array}{ll}3 & (17.6 \%) \\
6 & (30.0 \%)\end{array}$ & $\begin{array}{l}0 \\
0\end{array}$ & $\begin{array}{ll}19 & (28.8 \%) \\
35 & (43.8 \%)\end{array}$ \\
\hline Trace & $( \pm)$ & $\begin{array}{ll}7 & (46.7 \%) \\
7 & (38.9 \%)\end{array}$ & $\begin{array}{ll}9 & (45.0 \%) \\
7 & (24.1 \%)\end{array}$ & $\begin{aligned} 10 & (58.8 \%) \\
8 & (40.0 \%)\end{aligned}$ & $\begin{array}{ll}8 & (57.1 \%) \\
7 & (53.8 \%)\end{array}$ & $\begin{array}{ll}34 & (51.5 \%) \\
29 & (36.3 \%)\end{array}$ \\
\hline Positive & $(+)$ & $\begin{array}{l}1(6.6 \%) \\
0\end{array}$ & $\begin{array}{l}2(10.0 \%) \\
4(13.8 \%)\end{array}$ & $\begin{array}{ll}4 & (23.5 \%) \\
6 & (30.0 \%)\end{array}$ & $\begin{array}{ll}6 & (42.9 \%) \\
6 & (46.2 \%)\end{array}$ & $\begin{array}{ll}13 & (19.7 \%) \\
16 & (20.0 \%)\end{array}$ \\
\hline \multicolumn{7}{|l|}{ Glucosuria } \\
\hline Negative & $(-)$ & $\begin{array}{ll}13 & (86.7 \%) \\
18 & (100 \%)\end{array}$ & $\begin{array}{ll}15 & (75.0 \%) \\
21 & (72.4 \%)\end{array}$ & $\begin{aligned} 5 & (29.4 \%) \\
12 & (60.0 \%)\end{aligned}$ & $\begin{array}{l}1(7.1 \%) \\
2(15.4 \%)\end{array}$ & $\begin{array}{ll}34 & (51.5 \%) \\
53 & (66.3 \%)\end{array}$ \\
\hline Trace & $( \pm)$ & $\begin{array}{l}2(13.3 \%) \\
0\end{array}$ & $\begin{array}{ll}2 & (10.0 \%) \\
6 & (20.7 \%)\end{array}$ & $\begin{array}{ll}2 & (11.8 \%) \\
7 & (35.0 \%)\end{array}$ & $\begin{array}{ll}1 & (7.1 \%) \\
3 & (23.1 \%)\end{array}$ & $\begin{aligned} 7 & (10.6 \%) \\
16 & (20.0 \%)\end{aligned}$ \\
\hline Positive & $(+)$ & $\begin{array}{l}0 \\
0\end{array}$ & $\begin{array}{l}3(15.0 \%) \\
2(6.9 \%)\end{array}$ & $\begin{array}{rr}10 & (58.8 \%) \\
1 & (5.0 \%)\end{array}$ & $\begin{aligned} 12 & (85.7 \%) \\
8 & (61.5 \%)\end{aligned}$ & $\begin{array}{ll}25 & (37.9 \%) \\
11 & (13.8 \%)\end{array}$ \\
\hline
\end{tabular}

Proteinuria was examined with Uro-labstick-III ${ }^{\circledR}$ and glucosuria was examined with Tes-tape ${ }^{\circledR}$. The upper and lower columns depict the numbers and prevalences of men and women, respectively. 
青島・加藤・寺西・加須屋：カドミウム腎症のスクリーニング検査としての 尿タンパク，尿糖定性・定量試験の検討

は16.1 mg $/ \mathrm{d} l, \quad(+)$ の最低濃度は $23.3 \mathrm{mg} / \mathrm{d} l,( \pm)$ 判 定の濃度範囲は6.8〜 $47.3 \mathrm{mg} / \mathrm{d} l$ であった。すなわち, 尿タンパク濃度 $20 \mathrm{mg} / \mathrm{d} l$ 以上は（土）あるいは $(+)$ と 判定され，明らかな $(+)$ の判定は $45 \sim 50 \mathrm{mg} / \mathrm{d} l$ 以上で あった。

テス・テープによる尿糖定性試験では，(土）以上の陽 性率は男 $48.5 \%$ (32人)，女 $33.8 \%$ (27人) であった。尿 $\beta_{2}$-マイクログロブリン值別の陽性率は, 尿 $\beta_{2}$-マイクロ グロブリン值が高くなるにしたがい増加し, $30 \mathrm{mg} / \mathrm{g} ク$ レアチニン以上群の陽性率は85～93\%であった。テス・ テープ法の感度を知るために, 判定規準別に尿糖濃度分 布を検討すると，（一) の最高濃度は $9.9 \mathrm{mg} / \mathrm{d} l ，( \pm ）$ 判 定の濃度範囲は9.9 $14.3 \mathrm{mg} / \mathrm{d} l,(+)$ の最低濃度は $16.2 \mathrm{mg} / \mathrm{d} l$ であった。したがって，テス・テープによる 尿糖（土）の感度は $10 \mathrm{mg} / \mathrm{d} l$ であった。

なお多項目複合試験紙による尿糖判定結果は, (-)が 男 $75.8 \%$ (50人)，女 $87.5 \%$ (70人)，（土）が男 $15.2 \%$ (10 人), 女 $11.3 \%$ ( 9 人), (+) 以上が男 $9.1 \%$ ( 6 人), 女 $1.2 \%$ ( 1 人) であった。尿糖（士）の検出感度は $50 \mathrm{mg} /$ $\mathrm{d} l$ であった。

3 ）尿タンパクと尿糖を規準にしたカドミウム腎症の スクリーニング方法の検討

環境庁により実施されたカドミウム環境污染地域住民 健康調查 ${ }^{1)}$ における第 1 次スクリーニング規準は,「尿夕 ンパク $10 \mathrm{mg} / \mathrm{d} l$ 以上で，かつ尿糖（士）以上」とされて いる。検査法は尿タンパク定量が $\mathrm{K}-\mathrm{C}$ 法, 尿糖定性は酵 素試験紙法（テス・テープ）である。このスクリーニン グ規準について以下に検討した。

$\mathrm{CBB}$ 法による尿タンパク濃度と酵素法による尿糖濃 度による本対象例の分布を，男女別に Fig. 3 に示した。 尿タンパク濃度の幾何平均值（範囲）は，男 $16.4 \mathrm{mg} / \mathrm{d} l$ $(1.8 \sim 95.7 \mathrm{mg} / \mathrm{d} l)$, 女 $14.2 \mathrm{mg} / \mathrm{d} l(3.9 \sim 92.0 \mathrm{mg} / \mathrm{d} l)$ であり, $50 \mathrm{mg} / \mathrm{d} l$ 以上は男 $7.5 \%$ ( 5 例), 女 $3.8 \%$ ( 3 例), $10 \mathrm{mg} / \mathrm{d} l$ 以下は男女とも約 $30 \%$ (男 20 例, 女 26 例) であった。尿糖濃度の幾何平均值(範囲) は, 男 $12.7 \mathrm{mg} /$ $\mathrm{d} l(0.95 \sim 2900 \mathrm{mg} / \mathrm{d} l)$, 女6.80 mg/d $l(0.2 \sim 2430 \mathrm{mg} /$ $\mathrm{d} l), 10 \mathrm{mg} / \mathrm{d} l$ 以上は男 $47.0 \%$ (31例)，女 $35.0 \%$ (28例) であった。

1) で述べたように, $\mathrm{K}-\mathrm{C}$ 法による尿タンパク濃度 10 $\mathrm{mg} / \mathrm{d} l$ は CBB 法では $18 \mathrm{mg} / \mathrm{d} l$ に相当したので,ここで の尿タンパク濃度のスクリーニング值は $18 \mathrm{mg} / \mathrm{d} l$ とし た。また，テス・テープ（士）以上は，尿糖濃度 $10 \mathrm{mg} /$ $\mathrm{d} l$ 以上に相当したので, 尿糖濃度の規準值は $10 \mathrm{mg} / \mathrm{d} l$ とした。男女各対象において，尿タンパクと尿糖の両規

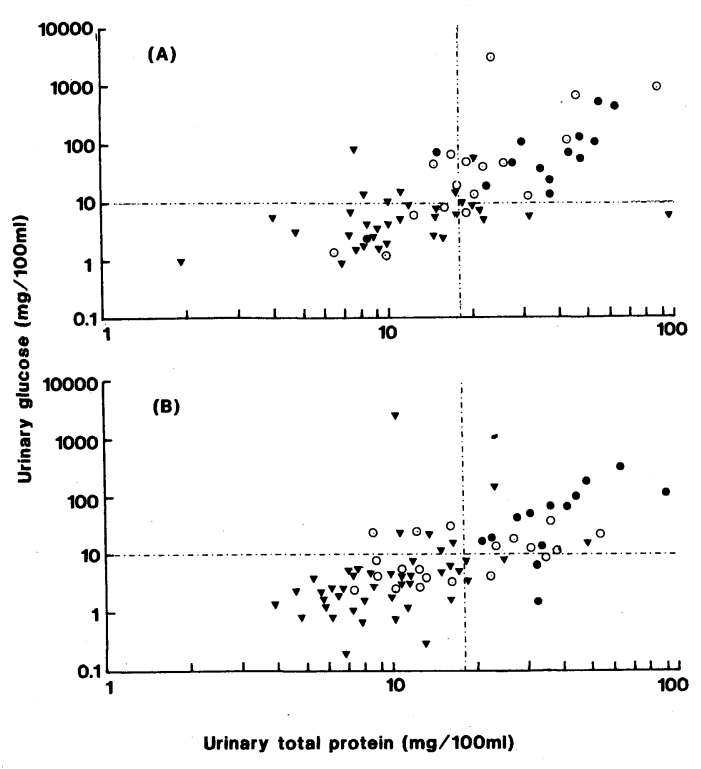

Fig. 3 Scattergram of protein and glucose in urine from subjects with $\beta_{2}$-microglobulinuria exceeding $30 \mathrm{mg} / \mathrm{g}$ creatinine $(O), 10$ to $30 \mathrm{mg} / \mathrm{g}$ creatinine $(O)$, and below $10 \mathrm{mg} / \mathrm{g}$ creatinine $(\nabla)$ found in the cadmium-polluted Jinzu River basin ; (A) : men $(n=66)$; $(B)$ : women $(n=80)$. The dashed lines represent cutoff levels of protein and glucose concentrations in urine.

準値を超えたのは，男23例（34.8\%)，女19例（23.8\%） であった。すなわち，尿 $\beta_{2}$-マイクログロブリン 1,000 $\mu \mathrm{g} / \mathrm{g}$ クレアチニン以上を示す尿細管障害例中の $25 \sim 35$ \%が，環境庁方式の第 1 次Aスクリーニング規準に該当 した。

尿細管障害の重症度を表す尿 $\beta_{2}$-マイクログロブリン 值別にスクリーニング率を検討すると, $30 \mathrm{mg} / \mathrm{g}$ クレア チニン以上では, 男12例, 女11例がスクリーニングされ, 男女ともに約 $85 \%$ のスクリーニング率であった。10～30 $\mathrm{mg} / \mathrm{g}$ クレアチニン例におけるそれは, 男 $52.9 \%$ ( 9 例),女30.0\%（6例）であった。

実際の運用においては,「尿タンパク $10 \mathrm{mg} / \mathrm{d} l$ 以上, または尿糖（士）以上」を第 1 次Aのスクリーニング規 準としている ${ }^{1)} こ の$ 規準を本対象例にあてはめると, 該 当率は, 男 $57.5 \%$ (38人), 女 $42.5 \%$ (34人) となった。 尿 $\beta_{2}$-マイクログロブリン值別のスクリーニング率は, $30 \mathrm{mg} / \mathrm{g}$ クレアチニン以上では, 男 $92.9 \%$ (13例), 女100

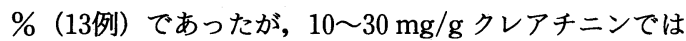
男 $76.8 \%$ (13例), 女55.0\% (11例) であった。 


\section{考察}

1 . 尿タンパク定量法の $\mathrm{K}-\mathrm{C}$ 法と $\mathrm{CBB}$ 法の比較

尿タンパク定量法の $\mathrm{K}-\mathrm{C}$ 法と CBB 法を比較したと ころ, 高い相関関係は得られたが両者の值は一致せず, $\mathrm{CBB}$ 法が約1.8倍高い值であった。 $\mathrm{K}-\mathrm{C}$ 法と CBB 法の 乘離に関し佐野らは，尿中にスルホサリチル酸可溶性夕 ンパク質の存在を見い出し7), 正常七ト尿では分子量 9.4 万の Tamm-Horsfall タンパク質, 疾患尿では $\alpha_{1}$-酸性 糖タンパク質がその主たるものと報告している8)。カド ミウム污染地住民では, 尿中低分子量タンパクの増加が 顕著であることから，今回みられた $\mathrm{K}-\mathrm{C}$ 法と $\mathrm{CBB}$ 法の 乘離の原因として，スルホサリチル酸可溶性タンパク質 の存在が考えられた。

2.カドミウム腎症における試験紙法による尿タンパク， 尿糖検查の問題点

試験紙法による尿タンパク検査は簡便なことから，留 障害のスクリーニングに広く使われている。しかしなが ら試駼紙法は, アルブミンには敏感であるが, グロブリ ンに対しては鈍感であるため, アルブミンに対しグロブ リンの比率が高い尿細管性タンパク尿の検出には不適当 である9)。本結果においても，1+以上の陽性率は約 $20 \%$ と低率であった。今回の試験紙法の感度は $45 \sim 50 \mathrm{mg} / \mathrm{d} l$ であり,アルブミン尿での試験紙法の感度 $30 \mathrm{mg} / \mathrm{d} l^{10}$ に 比較し低下していた。また尿タンパク濃度は, 大部分が $50 \mathrm{mg} / \mathrm{d} l$ 以下であり, 試験紙法の感度では見逃してしま うタンパク濃度であった。

テス・テープによる尿糖定性検査では, 弱陽性の判定 が黄色から緑色への変化をとらえる点で容易であり, そ の感度は $10 \mathrm{mg} / \mathrm{d} l$ であった。一方, 多項目試験紙での尿 糖 $( \pm$ ）の検出感度は $50 \mathrm{mg} / \mathrm{d} l$ とテス・テープ法の 5 分 の 1 であり, 尿糖濃度の低い腎性糖尿を捉えるには不適 切であった。

\section{3.カトドミウム腎症のスクリーニング方法の検討}

今回検討した環境庁による調査方式は, 昭和 51 年に改 訂されたものである ${ }^{11)}$ 。すなわち,それ以前の骨病変重視 の調查方式から，尿細管障害の検索を主体とした方式へ と改訂され, 低分子量タンパク尿, 尿細管リン再吸収率, 尿アミノ酸分析, 血液ガス分析の諸検査を含む, 非常に 高度な内容の方式である ${ }^{12)}$ 。この改訂した調查方式によ り実施された石川県, 長崎県, 兵庫県, 秋田県, 群馬県, 福島県, 大分県の 7 県のカドミウム污染地域住民健康調 查では, 57例のファンコニー症候群が見いだされた ${ }^{12)}$ 。昭 和54年から59年にわたって実施された富山県神通川流域
カドミウム污染地域住民健康調査では, 276例のファンコ ニー症候群が発見されている ${ }^{1)}$ 。斎藤ら ${ }^{13)}$ は, この方式で は対照地域住民のほとんどが低分子量タンパク尿検査の 段階（第 1 次 Bスクリーニング）でふるい落とされたと 報告している。

本報では, 尿 $\beta_{2}-$-マイクログロブリン $1,000 \mu \mathrm{g} / \mathrm{g}$ クレ アチニン以上の尿細管障害例を対象に, 第 1 次Aのスク リーニング規準について検討した結果,「尿タンパク 10 $\mathrm{mg} / \mathrm{d} l$ 以上で, かつ尿糖（土）以上」に該当した例は女 約 $25 \%$, 男約 $35 \%$ であった。城戸ら ${ }^{14)}$ は, 石川県梯川流 域カドミウム污染地住民を対象に同様の検討を行い, $12.4 \%$ の該当率であったと報告している。いずれにして も, 第 1 次 $\mathrm{A}$ のスクリーニング規準では, 尿 $\beta_{2}$-マイクロ グロブリン $1,000 \mu \mathrm{g} / \mathrm{g}$ クレアチニン以上の尿細管機能 障害例の約 $10 〜 30 \%$ がスクリーニングされるに留まった。 尿 $\beta_{2}$-マイクログロブリン排泄量は尿細管障害の程度を

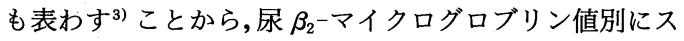
クリーニング率を検討すると, $30 \mathrm{mg} / \mathrm{g}$ クレアチニン以 上の高度の尿細管障害例では大部分がスクリーニングさ れたが，10〜 $30 \mathrm{mg} / \mathrm{g}$ クレアチニン例では $30 \sim 50 \%$ のス クリーニング率であった。すなわち, 尿 $\beta_{2}$-マイクログロ ブリン $10 \mathrm{mg} / \mathrm{g}$ クレアチニン以上を呈する明らかな尿 細管障害例の 50 ～70\%がスクリーニングされるに留まっ た。尿 $\beta_{2}$-マイクログロブリン $1 \sim 10 \mathrm{mg} / \mathrm{g}$ クレアチニ ンという初期の尿細管障害例では, 尿タンパク・尿糖を 規準にしたスクリーニング法ではとらえることはできな かった。以上のことから，カドミウム腎症をより軽症の ものからとらえるためには現在の方式を改訂し, $\beta_{2}$-マイ クログロブリンに代表される尿中低分子量タンパクを第 1 次のクスリーニング規準として, カドミウム污染地域 住民の健康調查を実施することが必要であろう。

$$
\text { まと め }
$$

カドミウム腎症のスクリーニング方法を検討するため に, 富山県神通川流域カドミウム污染地住民中, 尿 $\beta_{2}-$ マ

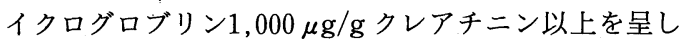
た男 66 人，女 80 人について尿タンパク，尿糖の定性・定 量試験を行い, 以下の結果を得た。

1 ）尿多項目複合試験紙によるタンパク陽性率は男 $19.7 \%$ ，女 $20.0 \%$ ，糖陽性率は男 $9.1 \%$ ，女 $1.2 \%$ あっ た。テス・テープ $( \pm)$ 以上の陽性率は男 $48.5 \%$, 女 33.8 \%であった。

2) 尿タンパク. 尿糖濃度の幾何平均值はそれぞれ, 男 $16.4,12.7 \mathrm{mg} / \mathrm{d} l$, 女 $14.2,6.8 \mathrm{mg} / \mathrm{d} l$ であり, 尿夕 
ンパク，尿糖は概して低い濃度であった。

3 ）環境庁によるカドミウム環境污染地住民健康調査 における第 1 次 Aのスクリーニング規準 (KingsburyClark 法による尿タンパク $10 \mathrm{mg} / \mathrm{d} l$ 以上, かつテス・テ ープ (土）以上）の該当率は，男34.8\% (23例)，女23.8 \% (19例) であった。尿 $\beta_{2}$-マイクログロブリン值別の該 当率は, $30 \mathrm{mg} / \mathrm{g}$ クレアチニン以上では男女各 $85 \%$, 10〜 $30 \mathrm{mg} / \mathrm{g}$ クレアチニンでは男 $52.9 \%$ ，女 $30.0 \%$ あ った。したがって，尿タンパクと尿糖を指標とした環境 庁方式のスクリーニング規準では, 尿 $\beta_{2}$-マイクログロ

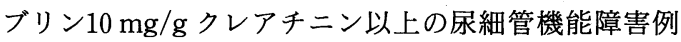
の確実なスクリーニングは困難であった。

\section{謝 辞}

多くの貴重な御助言を頂きました長崎大学医学部衛生 学教室斎藤 寛教授に深謝致します。なお本研究は昭和 60 年および 61 年度文部省科学研究費補助金（課題番号 60030029および61030052）によって行われた。

\section{文献}

1）「カドミウムによる環境污染地域住民健康調査」検討 委員会：カドミウムによる環境污染地域住民健康調 査，環境保健レポート，56，69-345（1989).

2) Aoshima, K.: Epidemiology of renal tubular dysfunction in the inhabitants of a cadmium polluted area in the Jinzu River basin in Toyama Prefecture, Tohoku J. exp. Med., 152, 151-172 (1987).

3）青島恵子, 岩田孝吉, 加須屋実：カドミ・ウム環境污 染による健康影響に関する研究，第 1 報，富山県神 通川流域カドミウム污染地住民の尿細管機能，とく に尿 $\beta_{2}$-マイクログロブリン值との関連において, 日衛誌，43，853-863 (1988).
4) 金井 泉, 金井正光：臨床検査法提要（改訂第29 版), p. 117, 金原出版, 東京 (1983).

5）斎藤 寛：腎機能検査，臨床検查，28，1479-1487 (1984).

6）榎本博光, 伊藤喜久：測定法変更による尿中 $\beta_{2}-$ ミ クログロブリン值の変化, 臨床検査, 31,1518 1521 (1987).

7）佐野紀代子，金森きよ子，中尾 真，中嶋克行，中 川裕史：尿蛋白定量法に関する研究一スルホサリチ ル酸法とクマシーブリリアントブルー G-250法との 乘離一，臨床病理，31，174-178（1983）.

8）中尾順子, 芝紀代子：色素を用いる微量定量, 臨床 検査, 30,877-882（1986）.

9）斎藤 寛, 古山 隆：尿細管性蛋白尿一一の概念, 出現機序, 臨床的意義, 臨床病理, 36 (特集), 173 -196 (1979).

10）エームス尿検査試験紙添付文書.

11）カドミウムによる環境污染暫定対策要領の一部（住 民健康調查方式）改正にういて（昭和51年 5 月 10 日 付環境庁企画調整局長通知).

12）斎藤 寛，中野篤浩：カドミウム環境污染と人間の 健康一生態中䓯学的アプローチー, “エコトキシコロ ジー”（大井 玄，鈴木継美，井村伸正編）, p. 119128, 篠原出版, 東京, (1983).

13）斎藤 寛, 蔀 幸三, 古川洋太郎, 塩路隆治, 古山 隆，吉永 馨：カドミウム腎障害一慢性カドミウム 中毒およびいわゆるイタイイタイ病の腎病変と骨軟 化症一，日本臨床，36，3431-3438，(1978）.

14）城戸照彦, 本多隆文, 石崎昌夫, 釣谷伊希子, 山田 裕一, 能川浩二：尿糖，尿蛋白を指標とした環境力 ドミウム暴露による住民健康調查の問題点，日衛誌， 45, 484 (1990).

（受付 1990年 7 月 12 日 受理 1990年 8 月18日） 